\title{
Policing the Arctic: The North Slope of Alaska
}

\author{
John E. Angell \& Lawrence C. Trostle
}

\section{Suggested citation}

Angell, John E.; \& Trostle, Lawrence C. (1993). "Policing the Arctic: The North Slope of Alaska". Paper presented at the annual meeting of the Western and Pacific Association of Criminal Justice Educators, Reno, NV, Oct 1993. Justice Center, University of Alaska Anchorage. (https://scholarworks.alaska.edu/handle/11122/10005).

\section{Summary}

Geographic size and lack of roads, among other factors, contribute to unique difficulties in providing effective law enforcement and public safety services to residents of the North Slope Borough of Alaska. Despite comprehensive plans laid in the mid-1970s, the North Slope Borough has not been successful in implementing a broad, multicultural community public safety organizational design. The more traditional professional law enforcement agency which has evolved is perceived by some people as having community and employee relations problems. This paper provides a brief history of law enforcement on the North Slope and presents selected data from a 1993 survey of employees of the North Slope Borough Department of Public Safety (NSBDPS). The data support a hypothesis that indigenous personnel with strong roots in a minority community will be more committed to the community police organization than would be employees without such roots.

\section{Additional information}

An abbreviated version of this paper, which excluded the NSBDPS employee survey results, was published as:

Trostle, Lawrence C.; \& Angell, John E. (1994). "Policing the Arctic: The North Slope of Alaska." Journal of Contemporary Criminal Justice 10(2): 95-108 (May 1994).

(http://dx.doi.org/10.1177/104398629401000203).

A related report with employee comments from the survey concerning Public Safety Officer (PSO) assignment lengths and rotation policies is available at https://scholarworks.alaska.edu/handle/11122/10007. 
POLICING THE ARCTIC:

THE NORTH SLOPE OF ALASKA

by

John E. Angell

Lawrence C. Trostle

Justice Center

University of Alaska Anchorage

JC 9402.01

Prepared for presentation at the annual meeting of the Western and Pacific Association of Criminal Justice Educators, Reno, October 1993. 


\section{Acknowledgments}

As with many endeavors, a few get the credit for the undertaking while others who have participated remain in obscurity. While we are willing to take sole responsibility for everything presented here, we would be remiss if we did not give credit where credit is due. Consequently, we would like to thank the following people for their contributions to this effort: James E. Christensen, current Director of Public Safety for the North Slope Borough; Dennis Packer, a former Director of Public Safety for the North Slope Borough; Melissa S. Green, the Justice Center's publications specialist; Amy Dellinger, who developed the codebook and performed data processing; and Cassie Atwell, who made suggestions, input data, and exhibited general all-around patience with us. 


\begin{abstract}
Geographic size and lack of roads, among other factors, contribute to unique difficulties in providing effective law enforcement and public safety services to residents of the North Slope Borough of Alaska. Despite comprehensive plans laid in the mid-1970s, the North Slope Borough has not been successful in implementing a broad, multicultural community public safety organizational design. The more traditional professional law enforcement agency which has evolved is perceived by some people as having community and employee relations problems. This paper provides a brief history of law enforcement on the North Slope and presents selected data from a 1993 survey of employees of the North Slope Borough Department of Public Safety (NSBDPS). The data support a hypothesis that indigenous personnel with strong roots in a minority community will be more committed to the community police organization than would be employees without such roots.
\end{abstract}




\section{POLICING THE ARCTIC:}

\section{THE NORTH SLOPE OF ALASKA}

Since the white man and Native first met on the icy Arctic shores over a century ago, they have sought a political and social system which would be mutually profitable and beneficial. No system has been harder to synthesize and adapt than the administration of justice and the legal norms of Western civilization. The early traders and whalers brought with them a set of laws which were alien to the Native population and difficult to understand. This cultural gap, and the difficulties in overcoming it, have led to decades of experimentation in law enforcement on the North Slope of the Brooks Range in Arctic Alaska.

- L. Davis Burton, A History of Law Enforcement on the North Slope

In sheer geographical area the North Slope Borough (NSB), located north of the Arctic Circle in Alaska, is the largest municipal government in the United States. (See Figure 1 for a map of the borough.) It includes the northernmost third of Alaska and stretches from the Chukchi Sea on the west to the Yukon Territory of Canada on the east. To put its geographical size into some perspective, the borough is approximately the size of California, Oregon, and Washington combined. The borough includes over 88,000 square miles with a population of approximately 6000 . (Woerner, 1986; Angell, 1977)

The 1990 census reported 5,979 NSB residents. About 73 percent of the permanent residents are Native peoples. Nearly all of them live in one of the eight communities or "villages" in the borough. The majority-approximately 3,400 people-live in Barrow, the northernmost city in Alaska and the seat of the North Slope Borough government. The other permanent borough communities of Point Hope, Point Lay, Wainwright, Atqasuk, Nuiqsut, Anaktuvuk Pass, and Kaktovik range from approximately 150 to 900 residents. Deadhorse at Prudhoe Bay is an oil company-owned work site designed to provide temporary accommodations for employees and oil equipment. It has no permanent residents.

The borough villages are primarily situated along the northern coast as far as 330 miles from Barrow. With one exception, the Dalton Highway, no roads cross the 


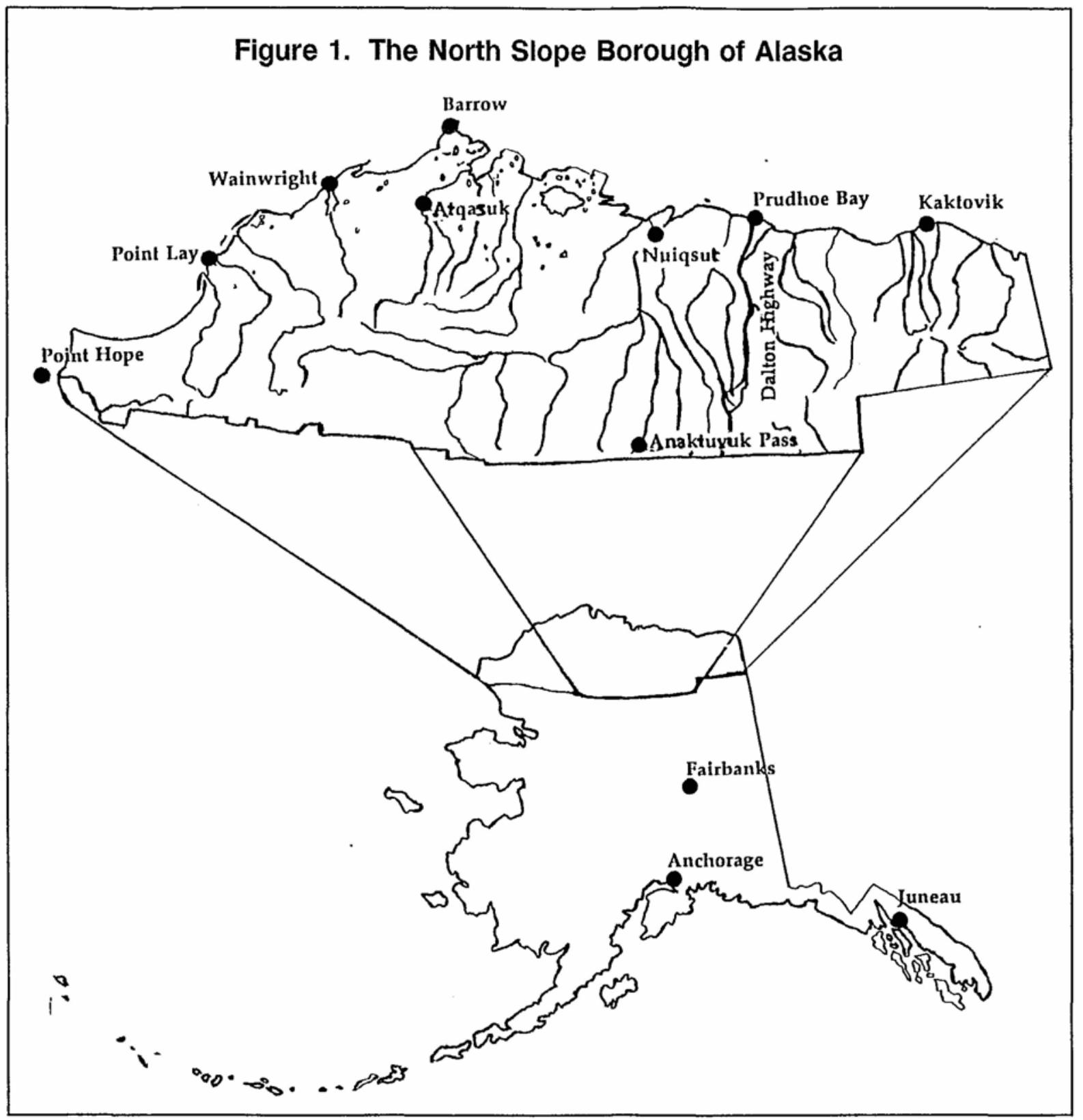

borough beyond the limits of the individual villages. The public relies on aircraft, offroad vehicles, and boats for transportation. Supplies from outside the borough are transported by aircraft or by barge during the summer months. The Dalton Highway, or "haul road," connects Fairbanks with Prudhoe Bay and the oil fields. This gravel road was built with federal highway funds, but it is largely a private roadway maintained by the oil companies and is not open to general public usage. (Messick, 1978) 
The cost of living in the Borough is approximately forty-five percent higher than in Anchorage, and a high proportion of Native residents are directly dependent on hunting and fishing for a significant portion of their food. Heavy activity by government and energy-related resource extraction businesses in recent years has made employment opportunities available in the borough, particularly at Barrow and Prudhoe Bay. The increased reliance on a cash economy during the last two decades has increased the stresses on the social system and individual citizens of the borough. These stresses seem to contribute to alcoholism, suicides, interpersonal violence, and group conflicts. The traditional social agencies have not been, nor are they currently, dealing adequately with the problems.

\section{Traditional Justice Administration}

Prior to the arrival of whites on the North Slope, the Inupiat people lived in small groups and survived by whaling, hunting, and food gathering. It appears the only permanent community on the Slope was at a western site now designated as Point Hope. This village of about 900 people is believed to have been occupied for over 2000 years, making it the longest continuously occupied community on the North American continent. (Spenser, 1976)

In the substantially nomadic communities of the North Slope, the family and the community provided the mechanism for dealing with antisocial behavior and crime. This social control system was not founded on individual rights, but on a network of obligations among members of the community which permitted survival in the vast Arctic environment. Although no obvious formal systems of laws or justice administration existed, there were time-honored patterns of social relations, and most deviant behavior was corrected by the family of the deviant person. (Spenser, 1976: 97) 
More serious offenses or interfamily disputes were usually handled by gossip and community condemnation, but on occasions where violence or deviance was considered serious, such as with lying, the accusations and defenses would be publicly aired before the entire community. If an individual continued to resist compliance with accepted norms for long periods, he might be abandoned to nature by the group or murdered by another community member, who would in turn be judged by the entire group. (Spenser, 1976: 98-99)

With the arrival of white whalers and trappers in the late 1800 s came more formal methods of justice based on English common law. Magistrate positions were created and Anglo-type processes instituted-although in a disjointed fashion-and coexisted with Native law ways. The federal government dispensed justice for several decades from the 1880s until the 1930s from a Treasury Department Revenue Cutter Service ship, the Bear, supplemented by U.S. Commissioners in Barrow and, at times, other sites on the Slope.

Following admission to statehood in 1959, the Alaska Court System was created and a Native, Sadie Neakok, was appointed as magistrate in 1960 to administer justice on the North Slope. With no police assigned to the Slope to assist her, she was left dependent on the community members whom she deputized for assistance with law enforcement. The first Alaska State Police officer, Tom Anderson, was assigned to Barrow in 1963.

The first written local ordinances were created by Barrow in 1965 to supplement Alaska statutes, and two Inupiat police officers were appointed to assist the state police officer. Nearly all of the deviance on the Slope was related to alcohol and the city instituted a work program in lieu of fines. The state police were on call in Nome and Barrow to assist with serious crimes in the villages, although response time could often be measured in days or weeks. These officers "acted without much regard for local social problems and mores..."(Moeller, 1977:5). 
During the late 1960s and the early 1970s the formalization of local police who supplemented the Alaska State Troopers on the Slope continued to grow. The new personnel were predominately whites hired from places outside the Slope and, in many cases, from police agencies in the lower 48 states. The practice of hiring from outside created many humorous situations, such as one involving a police officer who left the urban demonstrations and riots in California to accept a police chief job in Barrow. His first action as chief involved implementation of uniforms complete with riot helmets and night sticks. White police officers wearing polyester, blue police uniforms, and riot gear in a small, isolated Native community where temperatures range from zero to 50 degrees provides stark evidence of the limited understanding of Barrow Natives and their problems by those installed as police.

Kim Moeller (1979) observed that, as in most other parts of Alaska, "bush justice" on the North Slope is unique. Of the relationship between law enforcement and Native peoples, Moeller writes:

Because of socio-cultural differences in rural Alaska, there is a huge gap of experience between urban and bush communities and peoples. Native regions are comprised of indigenous peoples who do not have homogeneous populations. These populations are made up of wide varieties of persons from other regions. A major handicap is in educational levels and diverse social backgrounds and experiences. Law enforcement experience, in particular, is missing from the social structure of most native populations. Few have ever been police officers, few have ever been members of wellorganized and efficient police departments; and those who have, rarely have moved to another location from their original home towns. (Moeller, 1979: ii)

\section{Government}

The North Slope Borough government was organized as a first class borough and incorporated on July 1, 1972. A home rule charter for the Borough was adopted on April 30, 1974. The borough government consists of a seven-member assembly elected at large, and an elected mayor who has broad executive authority. 
State law delegates to first class boroughs governing powers in three general areas: assessment and taxation; education; and land use planning and zoning. In addition, villages and cities within a first class borough have the right to transfer any of their general police powers to the borough, and all of the NSB villages have done so.

Despite tremendous financial resources the borough obtained through oil property taxes in recent decades, the small population, great distances between communities, and subsistence economy in the borough have traditionally limited the quantity and quality of services governments were able to provide to North Slope residents. In the entire time prior to 1976, Barrow was the only Borough community to have full-time resident police officers. Barrow residents were uncomfortable with formal police officers, and few Native residents served as police officers. The chief and at least one of the police officers were always Anglo. Since the appointment of the first police officer, the police turnover rate has been high, and tense relations have existed between police and Native residents.

Areas outside of Barrow were primarily dependent for police services on the Alaska State Trooper who resided in Barrow. Although this trooper was occasionally assisted by part-time village police in Point Hope and Wainwright and another trooper who resided over 500 air miles away in Nome, the communications and transportation situation in the borough made it impossible for him to ensure citizens in outlying villages a quick response even in an emergency. Normally in an emergency a trooper could get to the scene of a serious police problem in a North Slope village within two to five days.

Fire and emergency medical services were more limited than law enforcement. The U.S. naval base five miles from Barrow had the only full-time fire department, and the Barrow Volunteer Fire Department was the only organized local firefighting operation on the Slope prior to creation of the North Slope Borough. Emergency 
medical services throughout the borough were provided by the U.S. Public Health Service, which maintained a hospital in Barrow, and community health aides in some of the villages.

\section{Department of Public Safety}

Officials of the North Slope Borough began to address the problem of inadequate public safety services in the spring of 1975 by retaining the NANA Development Corporation to study the problem of law enforcement and to recommend steps the borough might initiate to improve police services throughout the borough. NANA assigned M. James Messick and William Nix the responsibility for the public safety study.

After an intensive two-month effort, these consultants determined that the public safety workload and its distribution throughout the borough was inadequate to justify the expenditures required for specialized police, fire, and paramedic organizational arrangements commonly used in other areas of the United States. They further concluded that the nature of public safety problems in the borough was such that they could be adequately handled by intelligent, well-educated and trained, generalist public safety officers and local volunteers or part-timers.

They also concluded that many of the community relations problems were caused by police in the small villages concentrating their actions on "law enforcement" and making liberal use of their arrest powers. Consequently, they reasoned, expansion of the police role to include a broad array of helping activities would ensure that most contacts between local residents and officers would involve positive experiences for the citizens. The expanded community public safety role would contribute to a greater acceptance of the police by residents. They also decided that only the borough government had the revenue-generating capabilities to finance such public services for local communities. The most logical solution to the problem, concluded the 
consultants, lay in the North Slope Borough establishment of a Department of Public Safety, which would be staffed by both Native and non-Native personnel and be responsible for broad police, fire, emergency medical, and general services throughout the borough.

The North Slope Borough Department of Public Safety (NSBDPS) was to be staffed by borough Public Safety Officers residing in Barrow and part-time Village Public Safety Officers serving in the individual towns and villages. The local nature of the agency would facilitate local Native hiring and training. These officers would be augmented in emergencies by the Alaska State Troopers.

The borough accepted the recommendations and created a Department of Public Safety, beginning July 1, 1976. The City of Barrow transferred its police and jail facilities power to the borough on the same date, and the Barrow police personnel and facilities became the nucleus of the Department of Public Safety. Barrow police chief Kim Moeller, who strongly supported the concept, was offered and accepted the position of director. Other villages in the borough also transferred their authority to provide police protection and jail services to the borough.

\section{North Slope Department of Public Safety Goals}

As the North Slope Borough public safety plan began in 1976, the recommendations by NANA for the Department of Public Safety included both shortrange implementation-oriented and long-range operational goals. These goals were:

- Develop an immediate public safety response capability at the local level.

- Provide an increased level of and new public safety services that have heretofore not been available.

- Meet the requirements of public safety services within the borough in part by developing projects not generally within the scope and experience of traditional law enforcement agencies.

- Provide a highly visible borough program to all residents and enhance the image of the North Slope Borough as a leader in the successful delivery of public safety services on area-wide basis. 
- Develop a highly skilled, multidisciplinary force of professional Public Safety Officers to address a wide range of problems on an area-wide basis.

- Provide a meaningful program of minor dispute resolution that diverts the offender from formal processing within the criminal justice system.

These goals reflect the broad "community public safety" emphasis of the organization planners. The opportunity to rationally implement these goals was immediately hampered by a political decision on the part of the State of Alaska.

As the North Slope Borough started its public safety operation there was a general assumption that it would supplement, rather than replace, Alaska State Trooper activity in the borough. Within weeks of the formation of the North Slope Borough Department of Public Safety, the Alaska Department of Public Safety removed its resident trooper from Barrow to the pipeline camps and Prudhoe Bay in order to provide police service along the TransAlaska Pipeline and the "haul road." After negotiations in Barrow with the governor, attorney general, and commissioner of public safety, the Alaska Department of Public Safety Commissioner promised to assist the borough with any "major investigations" and to continue servicing Barrow on a periodic basis, by issuing driver licenses and serving processes.

The most significant impact of this state pullout was that the borough was forced to provide police services throughout its jurisdiction before it was fully organized or staffed to assume responsibility for meeting these obligations. It did not have the organization, facilities, equipment, or personnel in place to handle an area the size of the California, Oregon, and Washington combined. In fact, it had only eight officers for the implementation of the NSBDPS in July of 1976, but increased this number to sixteen by late 1977 .

The borough was forced to hire police officers who already met certification standards from other police agencies in the lower 48. Consequently, despite the best efforts of the first director to instill a generalist "community-oriented" philosophy in his organization, the effectiveness of this approach was limited. He had law 
enforcement officers who already knew what police officers are supposed to do-get the facts and enforce the laws. Further, borough public safety officers who were sent to training programs outside the borough were not treated as "real police" because they were "public safety officers."

Despite the potential for the community public safety concept adopted by the North Slope Borough, it was sidetracked immediately. While all employees had a general awareness of their broad public safety responsibility, most public safety officers considered the department's criminal apprehension duties to be both the most important and the most legitimate agency concerns (Angell, 1977).

Full implementation of the public safety concept was further impeded by resistance from the Indian Health Service and Village Health Aids and from volunteer fire department personnel, especially in Barrow where the fire chief was an influential Native resident who managed an efficient volunteer fire operation.

The last decade and a half have resulted in the law enforcement perspective being more formally accepted as the dominant role of the North Slope Borough Department of Public Safety. In its 1990-1991 annual report the NSBDPS presents its Mission Statement:

The mission of the North Slope Borough, Department of Public Safety is to protect the Constitutional guarantees of the public it serves, and to provide the professional services needed to sustain a community police relationship which promotes the safety and welfare of the public within the North Slope Borough.

Now related to this mission, is a series of goals. These goals have been established to accomplish what we have expressed in our Mission Statement. They are as follows:

- To enhance agency effectiveness and efficiency in the delivery of Public Safety services. crime.

- To increase our agency's capabilities in preventing and controlling

- To improve cooperation and coordination with other law enforcement agencies, and with other components of the criminal justice system.

- To increase citizen and staff confidence in the goals, objectives, policies and practices of the North Slope Borough Department of Public Safety (p.9). 
In 1989. L. Davis Burton, writing as the department historian, noted that the "generalist's responsibilities [of the NSBDPS] detracted from the officer's selfidentity as a policeman and these men who had trained to enforce laws traditionally were unhappy with what was viewed as a polluting of their profession"(p. 28).

The self-description of the NSBDPS in the 1993 Journal of the Alaska Peace Officers And Associates states, "Since its inception, the Department of Public Safety has evolved from a 'tri-service' organization with primary responsibility for police, fire and emergency medical services, to a dedicated police agency with peripheral involvement with fire and other emergency duties" (p. 259). Based on the early works of Angell (1977), Moeller (1979) and Messick (1978), this philosophy of the role currently held by the NSBDPS would not be necessarily be viewed as evolutionary or positive.

Contributing to the development of the current situation has been a progression of Directors of Public Safety, themselves: all Anglo; none natives of borough communities. Most directors who followed Moeller have been educated "outside," have had traditional law enforcement backgrounds, and hold a dominant view of police officers as "crime fighters." Despite its failure to assume the broad police, fire, and emergency medical role, the NSBDPS has grown under these directors to over ninety employees with over 50 public safety officers state-certified as police officers. Only one of these officers is a Native.

Without full implementation of the "community public safety" model and with a failure to include a significant contingent of indigenous Inupiat residents among the employees of the organization, the most significant question left unanswered is: Would a more effective social control organization have been produced by the model and the incorporation of indigenous Native residents into its primary operational and managerial roles? 


\section{Research Support for a Multicultural Community Social Control Operation}

Recent research into issues for organizational development of the North Slope Borough Department of Public Safety has produced data bearing on the possible value of a multicultural, service-oriented police work force which reflects the demographic and cultural make-up of the public. The data were derived from a job satisfaction instrument designed to obtain the opinions, preferences, and ideas of employees of the North Slope Borough Department of Public Safety. The instrument was administered to 90 NSBDPS employees in summer 1993. A total of 43 questionnaires were returned, of which 42 contained usable data. These returned questionnaires were completed by 29 sworn officers, all but one non-Natives, and 13 nonsworn employees, of whom seven were North Slope Borough Native residents.

The questions answered by these employees ranged from items related to reasons for becoming a NSBDPS employee to personal job satisfaction to organizational loyalty and perceptions of the NSBDPS's purpose and function.

Table 1 presents percentage summaries of nonsworn, Native, and sworn employee rankings of their reasons for becoming NSBDPS employees. About 82.8 percent of the sworn officers (Table 1A) ranked salary as among the top four reasons behind their decision, but only 17.1 percent (Table 1B) ranked the opportunity to provide needed services at the top. In contrast, over half the nonsworn and the Native employees ranked the opportunity to provide services as a high motivation

Table 1. Primary Reason for Becoming a North Slope Borough Department of Public Safety Employee

\begin{tabular}{lrccc} 
& Ranking & $\begin{array}{c}\text { Nonsworn } \\
\text { employees }\end{array}$ & $\begin{array}{c}\text { Native } \\
\text { employees }\end{array}$ & $\begin{array}{c}\text { Sworn } \\
\text { employees }\end{array}$ \\
\hline A. Best salary available & 1 & $7.7 \%$ & $0.0 \%$ & $55.2 \%$ \\
& 2 & 15.4 & 0.0 & 13.8 \\
& 3 & 30.5 & 0.0 & 6.9 \\
B. To provide a needed service & 4 & 38.5 & 0.0 & 6.9 \\
& Lower & 61.5 & 100.0 & 17.2 \\
& 1 & $15.4 \%$ & $0.0 \%$ & $0.0 \%$ \\
& 2 & 15.4 & 42.9 & 3.4 \\
& 3 & 15.4 & 14.3 & 3.4 \\
& 4 & 7.7 & 0.0 & 10.3 \\
& Lower & 46.2 & 42.9 & 82.9
\end{tabular}


factor and "the best salary available" was ranked low. None of the Inupiat Natives ranked salary in their top four reasons, and over 67 percent ranked "provide a needed service" within the top three reasons. One interpretation of these differences is that Anglo officers, on the whole, joined the department for the money and those employees with roots in the borough joined to assist others.

Given that the nonsworn and Native employees as a group have longer residency in Slope communities, the hypothesis that people with roots in the local community and culture are more committed to providing good service to their friends and neighbors seems reasonable and deserves further evaluation.

Tables 2A through $2 \mathrm{C}$ summarize the data from questions related to employee job satisfaction. Table 2A supports the conclusion that Native employees have the highest level of job satisfaction and, although all categories have a high level of overall satisfaction, sworn officers report the lowest level, with 20.7 percent reporting dissatisfaction. Only 15.4 percent of the nonsworn and none of the Natives reported being dissatisfied with their jobs.

Tables 2B and 2C show that both nonsworn (84.6\%) and Native (100\%) employees would be more likely than sworn officers $(62.1 \%)$ to take the same position again and to recommend their job to a friend (nonsworn, 84.6\%; Native, 85.7\%; sworn,

Table 2. Job Satisfaction

\begin{tabular}{|c|c|c|c|}
\hline & $\begin{array}{l}\text { Nonsworn } \\
\text { employees }\end{array}$ & $\begin{array}{c}\text { Native } \\
\text { employees }\end{array}$ & $\begin{array}{c}\text { Sworn } \\
\text { employees }\end{array}$ \\
\hline \multicolumn{4}{|l|}{ A. How satisfied are you with your job? } \\
\hline Completely satisfied & $7.7 \%$ & $14.3 \%$ & $6,9 \%$ \\
\hline Very satisfied & 53.8 & 57.1 & 41.4 \\
\hline Fairly satisfied & 23.1 & 28.6 & 27.6 \\
\hline Somewhat dissatisfied & 15.4 & 0.0 & 20.7 \\
\hline Very dissatisfied & 0.0 & 0.0 & 0.0 \\
\hline No response & 0.0 & 0.0 & 3.4 \\
\hline \multicolumn{4}{|l|}{ B. Would you take the same position with NSBDPS again? } \\
\hline Would not lake & $7.7 \%$ & $0.0 \%$ & $6.9 \%$ \\
\hline Would have second thoughts about taking it & 7.7 & 0.0 & 27.6 \\
\hline Would take it & 84.6 & 100.0 & 62.1 \\
\hline No response & 0.0 & 0.0 & 3.4 \\
\hline \multicolumn{4}{|l|}{ C. Would you recommend this job to a friend? } \\
\hline Would advise against it & $0.0 \%$ & $0.0 \%$ & $13.8 \%$ \\
\hline Would have second thoughts about recommending it & 15.4 & 14.3 & 27.6 \\
\hline Would recommend it & 84.6 & 85.7 & 55.2 \\
\hline No response & 0.0 & 0.0 & 3.4 \\
\hline
\end{tabular}


$55.2 \%$ ). One conclusion concerning these data might be that local residents who share the same values as the citizens they serve make more satisfied employees than those who do not have such common backgrounds.

Table 3 summarizes NSBDPS employee reports of their willingness to devote greater effort to ensuring the success of the NSBDPS and their reported level of loyalty to the department. All Native respondents and 92.3 percent of the nonsworn personnel expressed a willingness to work harder on behalf of the department. In contrast, only 61.4 percent of the sworn officers expressed such a willingness to increase their work effort.

Approximately 20.7 percent of the sworn officers indicated they have very little loyalty to the NSBDPS. None of the nonsworn or Native employees gave such an indication. All Native and 92.3 percent of the nonsworn personnel, as compared to 72.4 percent of the sworn officers, indicated loyalty to the NSBDPS.

Although the small total number of respondents hampers an ability to determine significance, the percentage differences provide evidence of the need for more substantive research in this area. Those employees with the strongest roots in the community also disproportionately report attitudes and commitments which are supportive of the NSBDPS organization.

Table 3. Dedication and Loyalty

Nonsworn

Native Sworn

employees employees employees

A. I am willing to work harder than I have to in order to help NSBDPS succeed.

$\begin{array}{rccc}\text { Strongly agree } & 30.8 \% & 14.3 \% & 17.2 \% \\ \text { Agree } & 61.5 & 85.7 & 44.2 \\ \text { Undecided } & 7.7 & 0.0 & 17.2 \\ \text { Disagree } & 0.0 & 0.0 & 6.9 \\ \text { Strongly disagree } & 0.0 & 0.0 & 6.9 \\ \text { No response } & 0.0 & 0.0 & 6.9\end{array}$

B. I feel very little loyalty to NSBDPS.

$\begin{array}{rccc}\text { Strongly agree } & 0.0 \% & 0.0 \% & 6.9 \% \\ \text { Agree } & 0.0 & 0.0 & 13.8 \\ \text { Undecided } & 7.7 & 0.0 & 3.4 \\ \text { Disagree } & 69.2 & 71.4 & 51.7 \\ \text { Strongly disagree } & 23.1 & 28.6 & 20.7 \\ \text { No response } & 0.0 & 0.0 & 3.4\end{array}$


Table 4. Community Relations

\begin{tabular}{|c|c|c|c|}
\hline & $\begin{array}{l}\text { Nonsworn } \\
\text { employees }\end{array}$ & $\begin{array}{l}\text { Native } \\
\text { employees }\end{array}$ & $\begin{array}{l}\text { Sworn } \\
\text { employees }\end{array}$ \\
\hline \multicolumn{4}{|l|}{$\begin{array}{l}\text { Most residents of the North Slope Borough are willing to } \\
\text { cooperate with the public safety officers. }\end{array}$} \\
\hline Strongly agree & $0.0 \%$ & $0.0 \%$ & $3.4 \%$ \\
\hline Agree & 38.5 & 42.9 & 17.2 \\
\hline Undecided & 7.7 & 14.3 & 17.2 \\
\hline Disagree & 53.8 & 42.9 & 37.9 \\
\hline Strongly disagree & 0.0 & 0.0 & 20.7 \\
\hline No response & 0.0 & 0.0 & 3.4 \\
\hline
\end{tabular}

Table 4 presents data on employees' perception of the willingness of North Slope Borough residents to cooperate with NSBDPS public safety officers. Both nonsworn and Native employees reported a higher level of agreement than did sworn officers, with the statement that most residents of the North Slope Borough were willing to cooperate with public safety officers. It may be that Native and nonsworn employees do receive better cooperation from borough residents than do sworn officers, and it may be a result of more amicable relations and trust among people who have had long personal relations.

A major issue among some NSBDPS employees is related to the length of time they must reside in a village community where they have been assigned. Some public safety officers have advocated the establishment of a 14-day, 12-hour on-duty schedule followed by 14 days off-duty. This arrangement would enable them to maintain a permanent residence in a city such as Fairbanks and commute to their work site in a village. Others have proposed shorter assignments in a village.

Table 5. Duration of Assignment in Local Community

Nonsworn Native Sworn employees employees employees

A. North Slope Borough public safety officers could do a better job if they didn't have to live as long in the community where they work.

$\begin{array}{rccc}\text { Strongly agree } & 0.0 \% & 0.0 \% & 20.7 \% \\ \text { Agree } & 7.7 & 0.0 & 13.8 \\ \text { Undecided } & 7.7 & 14.3 & 34.5 \\ \text { Disagree } & 76.9 & 71.4 & 17.2 \\ \text { Strongly disagree } & 7.7 & 14.3 & 10.3 \\ \text { No response } & 0.0 & 0.0 & 3.4\end{array}$

B. The duration of a public safety officer's assignment in one community is too short for the officer to develop the capacity to perform most effectively.

$\begin{array}{rlll}\text { Strongly agree } & 23.1 \% & 28.6 \% & 6.9 \% \\ \text { Agree } & 23.1 & 28.6 & 13.8 \\ \text { Undecided } & 23.1 & 14.3 & 19.2 \\ \text { Disagree } & 23.1 & 28.6 & 48.3 \\ \text { Strongly disagree } & 0.0 & 0.0 & 10.3 \\ \text { No response } & 7.7 & 0.0 & 3.4\end{array}$


Table 6. Law Enforcement Duties

Nonsworn Native Sworn

employees employees employees

I prefer to deal with law enforcement activities rather than

engage citizens in casual conversation.

$\begin{array}{rccc}\text { Strongly agree } & 0.0 \% & 0.0 \% & 10.3 \% \\ \text { Agree } & 0.0 & 0.0 & 3.4 \\ \text { Undecided } & 30.8 & 42.9 & 21.1 \\ \text { Disagree } & 38.5 & 28.6 & 51.7 \\ \text { Strongly disagree } & 30.8 & 28.6 & 6.9 \\ \text { No response } & 0.0 & 0.0 & 3.4\end{array}$

Table 5 data reveal that Alaska Native and nonsworn employee positions on the issues of village residency are more supportive of village residency for public safety officers than are the public safety officers themselves. Natives believe public safety officers would do a better job if they were assigned to live in the village where they work for longer periods.

Support for a hypothesis that Native and nonsworn employees are less willing to engage in law enforcement activities than sworn personnel can be found in Table 6 . Although only 13.7 percent of the sworn personnel indicated a preference for engaging in law enforcement activities rather than engaging in casual conversation, none of the Native or nonsworn employees indicated such a preference.

A majority of the sworn officers (65.5\%) who responded to the questionnaire indicated that they associate no job performance improvement with being Native, knowing local residents, or speaking Inupiat (Table 7). Only 21.1 percent indicated

\section{Table 7. Residence in Local Community}

\begin{tabular}{|c|c|c|c|}
\hline & $\begin{array}{l}\text { Nonsworn } \\
\text { employees }\end{array}$ & $\begin{array}{l}\text { Native } \\
\text { employees }\end{array}$ & $\begin{array}{l}\text { Sworn } \\
\text { employees }\end{array}$ \\
\hline \multicolumn{4}{|l|}{$\begin{array}{l}\text { A. A NSBDPS officer should not be expected to live in the village } \\
\text { where he or she works. }\end{array}$} \\
\hline $\begin{array}{lll}\text { Strongly agree } & \text { Sto }\end{array}$ & $0.0 \%$ & $0.0 \%$ & $20.7 \%$ \\
\hline Agree & 15.4 & 14.3 & 13.8 \\
\hline Undecided & 23.1 & 14.3 & 24.1 \\
\hline Disagree & 30.8 & 42.9 & 20.7 \\
\hline Strongly disagree & 0.0 & 28.6 & 17.2 \\
\hline $\begin{array}{ll}\text { No response } & \text { No }\end{array}$ & 0.0 & 0.0 & 3.4 \\
\hline \multicolumn{4}{|l|}{$\begin{array}{l}\text { B. I believe that most NSBDPS public safety and correctional } \\
\text { officers can do a better job if they are Natives of Borough } \\
\text { villages, know the local people, and are fluent in speaking } \\
\text { Inupiat. }\end{array}$} \\
\hline $\begin{array}{lll}\text { Strongly agree } & \text { Stros }\end{array}$ & $7.7 \%$ & $28.6 \%$ & $3.4 \%$ \\
\hline Agree & 15.4 & 28.6 & 20.7 \\
\hline Undecided & 7.7 & 0.0 & 6.9 \\
\hline Disagree & 30.8 & 42.9 & 24.1 \\
\hline Strongly disagree & 38.5 & 0.0 & 41.4 \\
\hline No response & 0.0 & 0.0 & 3.4 \\
\hline
\end{tabular}


that a public safety officer with these characteristics would do a better job. The responses of nonsworn employees were consistent with those of the officers. Over half of the Native employees (57.2\%), on the other hand, indicated a belief that such characteristics enhanced a public safety officer's job performance capabilities.

\section{Conclusion}

Despite comprehensive plans laid in the mid-1970s, the North Slope Borough has not been successful in implementing a broad, multicultural "community public safety" organizational design. The more traditional "professional" law enforcement agency which has evolved is perceived by some people as having community and employee relations problems. The data collected from North Slope Borough Department of Public Safety employees in the summer of 1993 reveal that sworn public safety officers, who are with one exception non-Native and trained primarily in law enforcement, present themselves as being less understanding of community and resident concerns than are Native employees and nonsworn employees who have deeper roots in the North Slope Borough than most sworn officers. Further, Native and nonsworn personnel as a whole report higher satisfaction with their jobs and the organization than sworn employees.

Although there are apparent weaknesses in the research, these data are sufficient for a hypothesis that the original, service-oriented organizational plan would have created a more effective public safety organization for the borough. Further, the data support a hypothesis that indigenous personnel with strong roots in a minority community will be more committed to the community police organization and the community and more satisfied with a community policing or public safety job than would an employee without such roots.

We believe these hypotheses merit further research in other communities. 


\section{References}

Alaska Police Officers Association. 1993. Journal of the Alaska Peace Officers and Associates 1993. Anchorage, AK: Alaska Peace Officers Association.

Angell, John E. 1977. A Study of the North Slope Department of Public Safety: A Technical Assistance Report. Report prepared for the North Slope Borough Department of Public Safety, Barrow, AK. Anchorage, AK: University of Alaska Anchorage, Justice Center.

Burton, L. Davis. 1989. A History of Law Enforcement on the North Slope. Barrow, AK: North Slope Borough Department of Public Safety.

Messick, M. James. 1978. A Review of Activities Within the North Slope Borough and Expected Impacts Related to Public Safety. Report prepared for the North Slope Borough Department of Public Safety, Barrow, AK.

Moeller, Kim L. 1977. The Challenge to the Police Role in Rural Alaska. Barrow, AK: North Slope Borough Department of Public Safety.

Barrow, AK: North Slope Borough Department of Public Safety.

North Slope Borough Department of Public Safety: 1990 - 1992 Annual Report. 1991. Barrow, AK: North Slope Borough Department of Public Safety.

Spenser, Robert F. 1976. The North Alaska Eskimo: A Study of Ecology and Society. New York: Dover.

Woerner, R.K. 1986. The Alaska Handbook. Jefferson, NC: McFarland \& Co. 


\section{Tables (Accessible)}

Note, 20 Feb 2019: These tables duplicate the content of the tables included in the original paper, but have been formatted to make them accessible for users of screen readers.

Table 1. Primary Reason for Becoming a North Slope Borough Department of Public Safety Employee

\begin{tabular}{rccc}
\multicolumn{4}{c}{ A. Best salary available } \\
Ranking & Nonsworn & Native & $\begin{array}{c}\text { Sworn } \\
\text { employees }\end{array}$ \\
employees & employees \\
\hline 1 & $7.7 \%$ & $0.0 \%$ & $55.2 \%$ \\
2 & $15.4 \%$ & $0.0 \%$ & $13.8 \%$ \\
3 & $30.5 \%$ & $0.0 \%$ & $6.9 \%$ \\
4 & $38.5 \%$ & $0.0 \%$ & $6.9 \%$ \\
Lower & $61.5 \%$ & $100.0 \%$ & $17.2 \%$ \\
\multicolumn{4}{c}{ B. To provide a needed service } \\
Ranking & employees & employees & employees \\
\hline 1 & $15.4 \%$ & $0.0 \%$ & $0.0 \%$ \\
2 & $15.4 \%$ & $42.9 \%$ & $3.4 \%$ \\
3 & $15.4 \%$ & $14.3 \%$ & $3.4 \%$ \\
4 & $7.7 \%$ & $0.0 \%$ & $10.3 \%$ \\
Lower & $46.2 \%$ & $42.9 \%$ & $82.9 \%$
\end{tabular}

Table 3. Dedication and Loyalty

\section{A. I am willing to work harder than I have to in} order to help NSBDPS succeed.

\begin{tabular}{rccc} 
[Response] & $\begin{array}{c}\text { Nonsworn } \\
\text { employees }\end{array}$ & $\begin{array}{c}\text { Native } \\
\text { employees }\end{array}$ & $\begin{array}{c}\text { Sworn } \\
\text { employees }\end{array}$ \\
\hline Strongly agree & $30.8 \%$ & $14.3 \%$ & $17.2 \%$ \\
Agree & $61.5 \%$ & $85.7 \%$ & $44.2 \%$ \\
Undecided & $7.7 \%$ & $0.0 \%$ & $17.2 \%$ \\
Disagree & $0.0 \%$ & $0.0 \%$ & $6.9 \%$ \\
Strongly disagree & $0.0 \%$ & $0.0 \%$ & $6.9 \%$ \\
No response & $0.0 \%$ & $0.0 \%$ & $6.9 \%$
\end{tabular}

B. I feel very little loyalty to NSBDPS.

\begin{tabular}{rccc} 
[Response] & $\begin{array}{c}\text { Nonsworn } \\
\text { employees }\end{array}$ & $\begin{array}{c}\text { Native } \\
\text { employees }\end{array}$ & $\begin{array}{c}\text { Sworn } \\
\text { employees }\end{array}$ \\
\hline Strongly agree & $0.0 \%$ & $0.0 \%$ & $6.9 \%$ \\
Agree & $0.0 \%$ & $0.0 \%$ & $13.8 \%$ \\
Undecided & $7.7 \%$ & $0.0 \%$ & $3.4 \%$ \\
Disagree & $69.2 \%$ & $71.4 \%$ & $51.7 \%$ \\
Strongly disagree & $23.1 \%$ & $28.6 \%$ & $20.7 \%$ \\
No response & $0.0 \%$ & $0.0 \%$ & $3.4 \%$
\end{tabular}

\section{Table 2. Job Satisfaction}

A. How satisfied are you with your job?

\begin{tabular}{rrrrr} 
[Response] & & $\begin{array}{c}\text { Nonsworn } \\
\text { employees }\end{array}$ & $\begin{array}{c}\text { Native } \\
\text { employees }\end{array}$ & $\begin{array}{c}\text { Sworn } \\
\text { employees }\end{array}$ \\
\hline Completely satisfied & $7.7 \%$ & $14.3 \%$ & $6.9 \%$ \\
Very satisfied & $53.8 \%$ & $57.1 \%$ & $41.4 \%$ \\
Fairly satisfied & $23.1 \%$ & $28.6 \%$ & $27.6 \%$ \\
Somewhat dissatisfied & $15.4 \%$ & $0.0 \%$ & $20.7 \%$ \\
Very dissatisfied & $0.0 \%$ & $0.0 \%$ & $0.0 \%$ \\
No response & $0.0 \%$ & $0.0 \%$ & $3.4 \%$
\end{tabular}

B. Would you take the same position with NSBDPS again?

\begin{tabular}{|c|c|c|c|}
\hline [Response] & $\begin{array}{l}\text { Nonsworn } \\
\text { employees }\end{array}$ & $\begin{array}{c}\text { Native } \\
\text { employees }\end{array}$ & $\begin{array}{c}\text { Sworn } \\
\text { employees }\end{array}$ \\
\hline Would not take it & $7.7 \%$ & $0.0 \%$ & $6.9 \%$ \\
\hline Would have second thoughts about taking it & $7.7 \%$ & $0.0 \%$ & $27.6 \%$ \\
\hline Would take it & $84.6 \%$ & $100.0 \%$ & $62.1 \%$ \\
\hline No response & $0.0 \%$ & $0.0 \%$ & $3.4 \%$ \\
\hline \multicolumn{4}{|l|}{ C. Would you recommend this job to a friend? } \\
\hline [Response] & $\begin{array}{l}\text { Nonsworn } \\
\text { employees }\end{array}$ & $\begin{array}{c}\text { Native } \\
\text { employees }\end{array}$ & $\begin{array}{c}\text { Sworn } \\
\text { employees }\end{array}$ \\
\hline Would advise against it & $0.0 \%$ & $0.0 \%$ & $13.8 \%$ \\
\hline Would have second thoughts about recommending it & $15.4 \%$ & $14.3 \%$ & $27.6 \%$ \\
\hline Would recommend it & $84.6 \%$ & $85.7 \%$ & $55.2 \%$ \\
\hline No response & $0.0 \%$ & $0.0 \%$ & $3.4 \%$ \\
\hline
\end{tabular}

Table 4. Community Relations

Most residents of the North Slope Borough are willing to cooperate with the public safety officers.

\begin{tabular}{rrcc} 
[Response] & $\begin{array}{c}\text { Nonsworn } \\
\text { employees }\end{array}$ & $\begin{array}{c}\text { Native } \\
\text { employees }\end{array}$ & $\begin{array}{c}\text { Sworn } \\
\text { employees }\end{array}$ \\
\hline Strongly agree & $0.0 \%$ & $0.0 \%$ & $3.4 \%$ \\
Agree & $38.5 \%$ & $42.9 \%$ & $17.2 \%$ \\
Undecided & $7.7 \%$ & $14.3 \%$ & $17.2 \%$ \\
Disagree & $53.8 \%$ & $42.9 \%$ & $37.9 \%$ \\
Strongly disagree & $0.0 \%$ & $0.0 \%$ & $20.7 \%$ \\
No response & $0.0 \%$ & $0.0 \%$ & $3.4 \%$
\end{tabular}


Table 5. Duration of Assignment in Local Community

A. North Slope Borough public safety officers could to a better job if they didn't have to live as long in the community where they work.

\begin{tabular}{rccc} 
[Response] & $\begin{array}{c}\text { Nonsworn } \\
\text { employees }\end{array}$ & $\begin{array}{c}\text { Native } \\
\text { employees }\end{array}$ & $\begin{array}{c}\text { Sworn } \\
\text { employees }\end{array}$ \\
\hline Strongly agree & $0.0 \%$ & $0.0 \%$ & $20.7 \%$ \\
Agree & $7.7 \%$ & $0.0 \%$ & $13.8 \%$ \\
Undecided & $7.7 \%$ & $14.3 \%$ & $34.5 \%$ \\
Disagree & $76.9 \%$ & $71.4 \%$ & $17.2 \%$ \\
Strongly disagree & $7.7 \%$ & $14.3 \%$ & $10.3 \%$ \\
No response & $0.0 \%$ & $0.0 \%$ & $3.4 \%$
\end{tabular}

B. The duration of a public safety officer's assignment in one community is too short for the officer to develop the capacity to perform most effectively.

\begin{tabular}{rccc} 
[Response] & $\begin{array}{c}\text { Nonsworn } \\
\text { employees }\end{array}$ & $\begin{array}{c}\text { Native } \\
\text { employees }\end{array}$ & $\begin{array}{c}\text { Sworn } \\
\text { employees }\end{array}$ \\
\hline Strongly agree & $23.1 \%$ & $28.6 \%$ & $6.9 \%$ \\
Agree & $23.1 \%$ & $28.6 \%$ & $13.8 \%$ \\
Undecided & $23.1 \%$ & $14.3 \%$ & $19.2 \%$ \\
Disagree & $23.1 \%$ & $28.6 \%$ & $48.3 \%$ \\
Strongly disagree & $0.0 \%$ & $0.0 \%$ & $10.3 \%$ \\
No response & $7.7 \%$ & $0.0 \%$ & $3.4 \%$
\end{tabular}

Table 7. Residence in Local Community

A. A NSBDPS officer should not be expected to live in the village where he or she works.

\begin{tabular}{rccc} 
[Response] & $\begin{array}{c}\text { Nonsworn } \\
\text { employees }\end{array}$ & $\begin{array}{c}\text { Native } \\
\text { employees }\end{array}$ & $\begin{array}{c}\text { Sworn } \\
\text { employees }\end{array}$ \\
\hline Strongly agree & $0.0 \%$ & $0.0 \%$ & $20.7 \%$ \\
Agree & $15.4 \%$ & $14.3 \%$ & $13.8 \%$ \\
Undecided & $23.1 \%$ & $14.3 \%$ & $24.1 \%$ \\
Disagree & $30.8 \%$ & $42.9 \%$ & $20.7 \%$ \\
Strongly disagree & $0.0 \%$ & $28.6 \%$ & $17.2 \%$ \\
No response & $0.0 \%$ & $0.0 \%$ & $3.4 \%$
\end{tabular}

B. I believe that most NSBDPS public safety and correctional officers can do a better job if they are Natives of Borough villages, know the local people, and are fluent in speaking Inupiaq.

\begin{tabular}{rccc} 
[Response] & $\begin{array}{c}\text { Nonsworn } \\
\text { employees }\end{array}$ & $\begin{array}{c}\text { Native } \\
\text { employees }\end{array}$ & $\begin{array}{c}\text { Sworn } \\
\text { employees }\end{array}$ \\
\hline Strongly agree & $7.7 \%$ & $28.6 \%$ & $3.4 \%$ \\
Agree & $15.4 \%$ & $28.6 \%$ & $20.7 \%$ \\
Undecided & $7.7 \%$ & $0.0 \%$ & $6.9 \%$ \\
Disagree & $30.8 \%$ & $42.9 \%$ & $24.1 \%$ \\
Strongly disagree & $38.5 \%$ & $0.0 \%$ & $41.4 \%$ \\
No response & $0.0 \%$ & $0.0 \%$ & $3.4 \%$
\end{tabular}

\section{Table 6. Law Enforcement Duties}

I prefer to deal with law enforcement activities rather than engage citizens in casual conversation.

\begin{tabular}{rccc} 
[Response] & $\begin{array}{c}\text { Nonsworn } \\
\text { employees }\end{array}$ & $\begin{array}{c}\text { Native } \\
\text { employees }\end{array}$ & $\begin{array}{c}\text { Sworn } \\
\text { employees }\end{array}$ \\
\hline Strongly agree & $0.0 \%$ & $0.0 \%$ & $10.3 \%$ \\
Agree & $0.0 \%$ & $0.0 \%$ & $3.4 \%$ \\
Undecided & $30.8 \%$ & $42.9 \%$ & $21.1 \%$ \\
Disagree & $38.5 \%$ & $28.6 \%$ & $51.7 \%$ \\
Strongly disagree & $30.8 \%$ & $28.6 \%$ & $6.9 \%$ \\
No response & $0.0 \%$ & $0.0 \%$ & $3.4 \%$
\end{tabular}

